University of Wollongong

Research Online

Faculty of Engineering - Papers (Archive)

Faculty of Engineering and Information

Sciences

$1-1-2011$

\title{
Effects of cu and fe doping on raman spectra and on the structural and magnetic properties of ErMnO3
}

\author{
Peng Liu \\ University of Wollongong, pl990@uowmail.edu.au \\ Zhenxiang Cheng \\ University of Wollongong, cheng@uow.edu.au \\ Yi Du \\ University of Wollongong, ydu@uow.edu.au \\ Xiaolin Wang \\ University of Wollongong, xiaolin@uow.edu.au
}

Follow this and additional works at: https://ro.uow.edu.au/engpapers

Part of the Engineering Commons

https://ro.uow.edu.au/engpapers/1346

\section{Recommended Citation}

Liu, Peng; Cheng, Zhenxiang; Du, Yi; and Wang, Xiaolin: Effects of cu and fe doping on raman spectra and on the structural and magnetic properties of ErMnO3 2011, 1-3.

https://ro.uow.edu.au/engpapers/1346

Research Online is the open access institutional repository for the University of Wollongong. For further information contact the UOW Library: research-pubs@uow.edu.au 


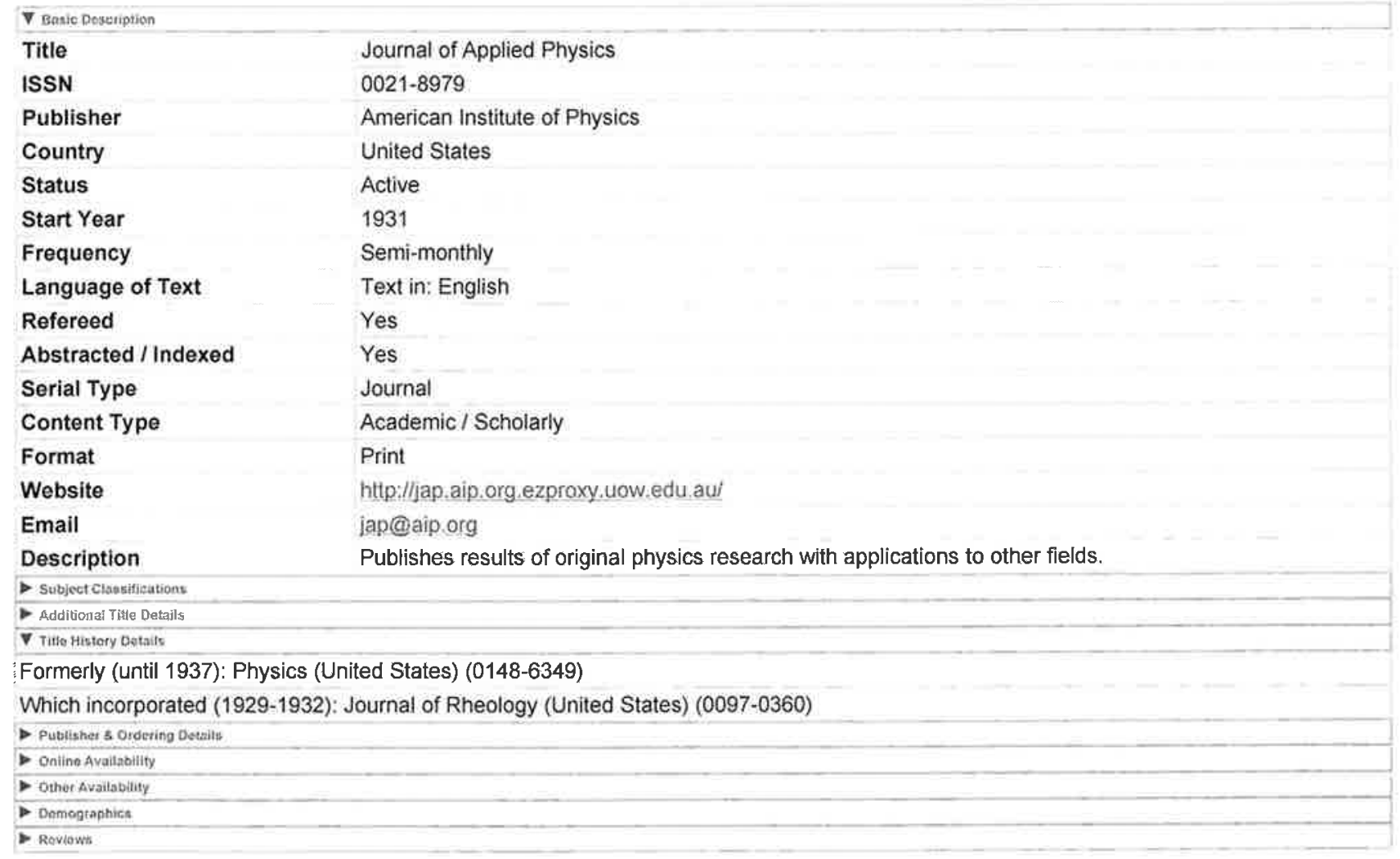

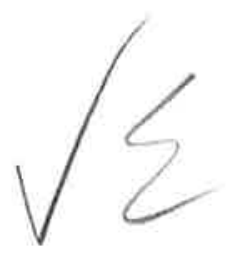




\title{
Effects of $\mathrm{Cu}$ and Fe doping on Raman spectra and on the structural and magnetic properties of $\mathrm{ErMnO}_{3}$
}

\author{
P. Liu, Z. X. Cheng, ${ }^{\text {a) }}$ Y. Du, and X. L. Wang \\ Institute for Superconducting and Electronics Materials, University of Wollongong, NSW 2519, Australia
}

(Presented 17 November 2010; received 28 September 2010; accepted 8 November 2010; published online 22 March 2011)

\begin{abstract}
Single phase $\mathrm{ErMe}_{x} \mathrm{Mn}_{1-\mathrm{x}} \mathrm{O}_{3}(\mathrm{Me}=\mathrm{Cu}, \mathrm{Fe} ; 0 \leq \mathrm{x} \leq 0.1)$ samples were synthesized by the solid state reaction method. The differences between the doping effects on the Raman spectra and on the structural, magnetic, and thermal properties of the two systems have been systematically investigated. In the $\mathrm{ErCu}_{\mathrm{x}} \mathrm{Mn}_{1-\mathrm{x}} \mathrm{O}_{3}$ system, lattice parameter $\boldsymbol{a}$ increases with doping, while lattice parameter $c$ decreases. It is more complicated in the $\mathrm{ErFe}_{\mathrm{x}} \mathrm{Mn}_{1-\mathrm{x}} \mathrm{O}_{3}$ system, where lattice parameter $\boldsymbol{a}$ decreases with doping, while lattice parameter $c$ is enhanced after an initial slight decrease. Raman spectra show that the phonon peaks of $\mathrm{ErFe}_{\mathrm{x}} \mathrm{Mn}_{\mathrm{I}-\mathrm{x}} \mathrm{O}_{3}$ slightly shift to higher frequencies with doping, while those of $\mathrm{ErCu}_{\mathrm{x}} \mathrm{Mn}_{1-\mathrm{x}} \mathrm{O}_{3}$ apparently shift toward lower frequencies. Heat capacity data indicates that the Néel temperature of $\mathrm{ErMnO}_{3}$ is reduced to $61 \mathrm{~K}$ for $\mathrm{ErCu}_{0.1} \mathrm{Mn}_{0.9} \mathrm{O}_{3}$ by $\mathrm{Cu}$ doping, whereas it is slightly enhanced to $79 \mathrm{~K}$ for $\mathrm{ErFe}_{0,1} \mathrm{Mn}_{0.9} \mathrm{O}_{3}$ through $\mathrm{Fe}$ doping. (C) 2011 American Institute of Physics. [doi:10.1063/1.3540695]
\end{abstract}

\section{INTRODUCTION}

Multiferroics are a class of materials that exhibits coupling between ferroelectric and magnetic orderings in the same phase. ${ }^{1-4}$ As additional degrees of freedom in designing conventional devices are allowed by the coupling, multiferroic materials would be of great value in numerous potential applications, such as multistate memory elements, magnetic field sensors, and transducers. ${ }^{5,6} \mathrm{ErMnO}_{3}$ is a notable multiferroic material that belongs to the series of hexagonal rare earth manganites $\mathrm{RMnO}_{3}(\mathrm{R}=$ rare earth $)$ characterized by a typical triangular magnetic structure with great frustration. $\mathrm{ErMnO}_{3}$ exhibits a ferroelectric (FE) transition at $588 \mathrm{~K}$ and an antiferromagnetic (AFM) transition at $77 \mathrm{~K}$. The strong coupling between the FE and AFM orderings is verified by a clear anomaly in the dielectric constant around the Néel temperature $\left(\mathrm{T}_{\mathrm{N}}\right){ }^{7}$ The crystal structure comprises layers of corner-sharing $\mathrm{MnO}_{5}$ trigonal bipyramids with two apical $\left(\mathrm{O}_{\mathrm{I}}, \mathrm{O}_{2}\right)$ oxygen atoms and a triangular base of nonequivalent $\mathrm{O}_{3}$ and $\mathrm{O}_{4}$ oxygen atoms. Er atoms with two symmetric sites are situated between the bipyramidal layers. The AFM ordering in $\mathrm{ErMnO}_{3}$ is ascribed to the in-plane triangular AFM structure of $\mathrm{Mn}^{3+}$ ions. ${ }^{8}$

In order to successfully use multiferroic materials in practical applications, the most important criterion is that the coupling between the ferroelectric and magnetic ordering occurs close to room temperature. Thus, it is necessary to enhance the extremely low $\mathrm{T}_{\mathrm{N}}$ of $\mathrm{ErMnO}_{3}$ through chemical doping. In our previous paper, a study of divalent alkaline-earth $\mathrm{Cu}$ ion doped $\mathrm{ErMnO}_{3}$, it is shown that the crystal structure becomes more distorted due to Jahn-Teller $\mathrm{Cu}^{2+}$ ions and the $\mathrm{T}_{\mathrm{N}}$ is reduced with doping. ${ }^{9}$ Hence, it is of significance to search for other effective dopants. The $\mathrm{Fe}^{3+}$ ion, which is not a Jahn-Teller

\footnotetext{
a) Author to whom correspondence should be addressed. Electronic mail
} cheng@uow.edu.au. ion, is expected to result in very different doping effects on $\mathrm{ErMnO}_{3}$ from the $\mathrm{Cu}^{2+}$ ions. In the present study, the $\mathrm{Fe}$ and $\mathrm{Cu}$ doping effects on the Raman spectra and on the structural, magnetic, and thermal properties of $\mathrm{ErMnO}_{3}$ have been systematically investigated. Moreover, the differences between these two doping systems are also compared in detail.

Polycrystalline samples of $\mathrm{ErMe}_{\mathrm{x}} \mathrm{Mn}_{1-\mathrm{x}} \mathrm{O}_{3}(0 \leq \mathrm{x} \leq$ 0.1 ) were synthesized by a conventional solid-state reaction method from stoichiometric mixtures of $\mathrm{Er}_{2} \mathrm{O}_{3}, \mathrm{CuO}, \mathrm{Fe}_{2} \mathrm{O}_{3}$, and $\mathrm{MnCO}_{3}$ powders. The experimental detail of sintering, Rietveld refinement, and measurements of $x$-ray diffraction (XRD) patterns and of magnetic and thermal properties are given in our previous paper. ${ }^{9}$ In addition, Raman spectra with Raman shifts ranging from 200 to $800 \mathrm{~cm}^{-1}$ were collected at room temperature by a laser Raman spectrometer (HB320, HORIBA Jobin Yvon). An $\mathrm{Ar}^{+}$gas laser with wavelength of $632.8 \mathrm{~nm}$ was used for excitation.

Figure 1 shows typical XRD patterns of $\mathrm{ErMe}_{\mathrm{x}} \mathrm{Mn}_{\mathrm{I}-\mathrm{x}} \mathrm{O}_{3}$ $(x=0,0.05,0.1)$ samples. All the samples are single phase

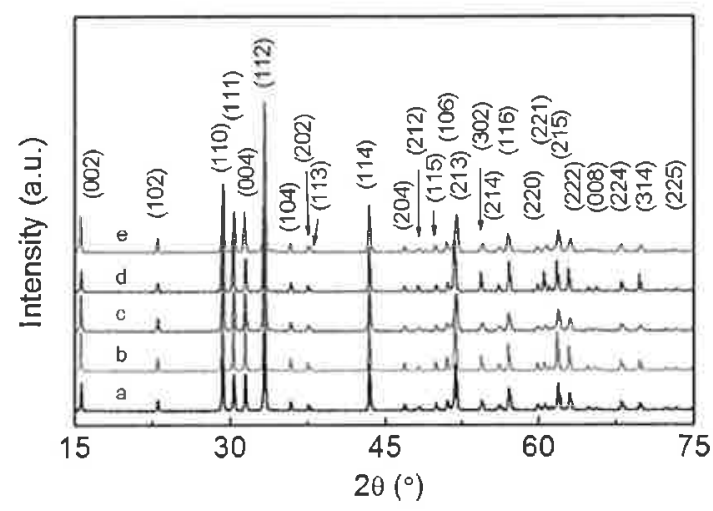

FIG. 1. (Color online) XRD patterns of (a) $\mathrm{ErMnO}_{3}$, (b) $\mathrm{ErCu}_{0.05} \mathrm{Mn}_{0.95} \mathrm{O}_{3}$ (c) $\mathrm{ErFe}_{0.05} \mathrm{Mn}_{0.95} \mathrm{O}_{3}$, (d) $\mathrm{ErCu}_{0.1} \mathrm{Mn}_{0.9} \mathrm{O}_{3}$, (e) $\mathrm{ErFe}_{0.1} \mathrm{Mn}_{0.9} \mathrm{O}_{3}$ collected at room temperature. 

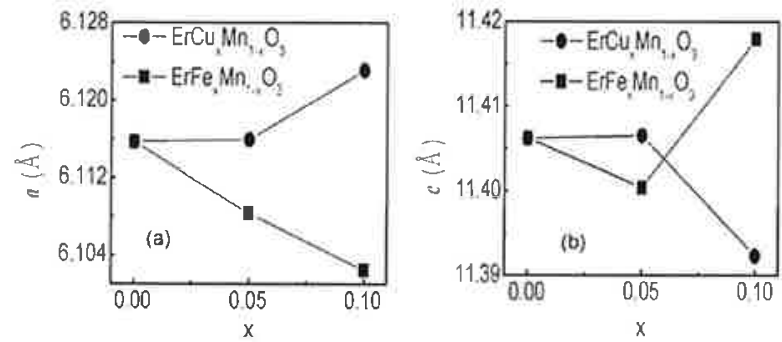

FIG. 2. Doping variations of (a) lattice parameter $a$ and (b) lattice parameter $c$ of $\mathrm{ErMe}_{x} \mathrm{Mn}_{\mathrm{I}-\mathrm{x}} \mathrm{O}_{3}(\mathrm{Me}=\mathrm{Cu}, \mathrm{Fe})$.

without any second phase observed. Each XRD pattern can be indexed to the hexagonal phase with $\mathrm{P}_{3} \mathrm{~cm}$ space group, in agreement with a previous report. ${ }^{10}$ Figure 2 shows the variations of the lattice parameters of the $\mathrm{ErMe}_{\mathrm{x}} \mathrm{Mn}_{1-\mathrm{x}} \mathrm{O}_{3}$ samples with the doping. Lattice parameter $\boldsymbol{a}$ in $\mathrm{ErCu}_{\mathrm{x}}$ $\mathrm{Mn}_{1-x} \mathrm{O}_{3}$ increases with increasing doping level, while in $\mathrm{ErFe}_{\mathrm{x}} \mathrm{Mn}_{1-\mathrm{x}} \mathrm{O}_{3}$, it decreases with higher $\mathrm{Fe}$ content. Obviously, lattice parameter $a$ in $\mathrm{Cu}$ doped samples is larger than in the corresponding $\mathrm{Fe}$ doped samples. Lattice parameter $c$ of $\mathrm{ErCu}_{\mathrm{x}} \mathrm{Mn}_{1-\mathrm{x}} \mathrm{O}_{3}$ remains nearly constant at $\mathrm{x} \leq 0.05$, which is followed by an apparent decrease up to $\mathrm{x}=0.1$. However, lattice parameter $c$ of Fe doped samples is reduced at low doping levels, with an ensuing increase at high doping levels. As $\mathrm{Mn}^{3+}\left(3 \mathrm{~d}^{4}\right), \mathrm{Cu}^{2+}\left(3 \mathrm{~d}^{9}\right)$, and $\mathrm{Fe}^{3+}\left(3 \mathrm{~d}^{5}\right)$ ions are situated in the trigonal bipyramidal crystal field of $\mathrm{Mn} / \mathrm{Me}$ $\mathrm{O}_{5}$ polyhedra, $\mathrm{Mn}^{3+}$ and $\mathrm{Cu}^{2+}$ ions are Jahn-Teller ions with ionic radii of $75.3 \mathrm{pm}$ and $87 \mathrm{pm}$, respectively, whereas $\mathrm{Fe}^{3+}$ ions with an ionic radius of $63 \mathrm{pm}$ are not Jahn-Teller ions. In $\mathrm{ErMnO}_{3}$, the $\mathrm{Mn}-\mathrm{O}$ bond length along the $c$ axis $(1.87 \AA)$ is much shorter than that in the $a b$ plane $(2.05 \AA)$ due to strong Jahn-Teller distortion. In general, variations of the lattice parameters in these two systems are ascribed to the combination of the Jahn-Teller effect and the ionic sizes of the doping elements. The overwhelming enhancements of the Jahn-Teller effect in the $\mathrm{Cu}$ doped samples are responsible for the dramatic increase in the $a$ axis and decrease in the $c$ axis with higher doping levels. In comparison, the decreases in the lattice parameters $a$ and $c$ of $\mathrm{ErFe}_{x} \mathrm{Mn}_{1-\mathrm{x}} \mathrm{O}_{3}$ are caused by the small ionic size of $\mathrm{Fe}^{3+}$ ions, while the

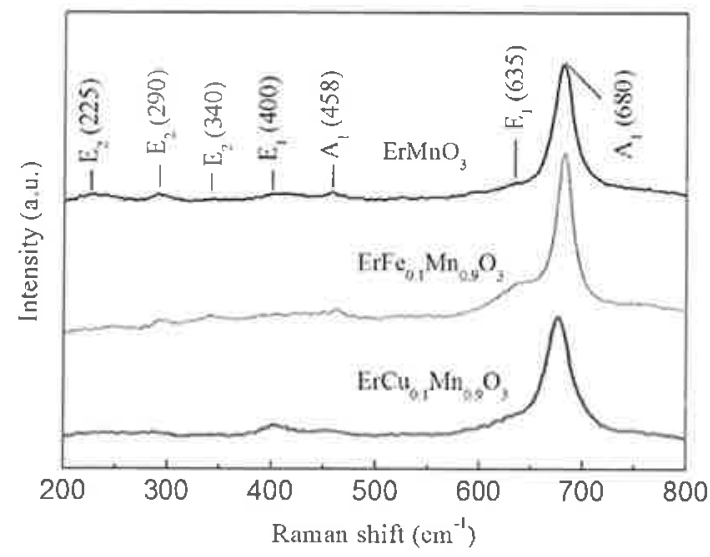

FIG. 3. (Color online) Raman spectra of $\mathrm{ErMe}_{x} \mathrm{Mn}_{1-\mathrm{x}} \mathrm{O}_{3}(\mathrm{Me}=\mathrm{Cu}, \mathrm{Fe}$; $\mathrm{x}=0,0.1$ ) measured at room temperature.
TABLE I. Observed Raman-active mode frequencies of $\mathrm{ErMe}_{\mathrm{x}} \mathrm{Mn}_{1-\mathrm{x}} \mathrm{O}_{3}$ $(\mathrm{Me}=\mathrm{Cu}, \mathrm{Fe} ; \mathrm{x}=0,0.1)$.

\begin{tabular}{lcccc}
\hline \hline $\begin{array}{l}\text { Directions of the largest } \\
\text { atomic displacements }\end{array}$ & Mode & $\mathrm{x}=0$ & $\begin{array}{c}\mathrm{Me}=\mathrm{Fe}, \\
\mathrm{x}=0.1\end{array}$ & $\begin{array}{c}\mathrm{Me}=\mathrm{Cu}, \\
\mathrm{x}=0.1\end{array}$ \\
\hline$+x, y\left(\mathrm{O}_{1}, \mathrm{O}_{2}\right)-x, y(\mathrm{Mn})$ & $\mathrm{A}_{1}$ & 458 & 463 & 455 \\
$+z\left(\mathrm{O}_{1}\right)-z\left(\mathrm{O}_{2}\right)$ & $\mathrm{A}_{1}$ & 680 & 683 & 675 \\
$x, y\left(\mathrm{O}_{3}\right)-x, y\left(\mathrm{O}_{4}\right)$ & $\mathrm{E}_{1}$ & 635 & 638 & \\
$+x, y\left(\mathrm{O}_{1}\right)-x, y\left(\mathrm{O}_{2}\right)$ & $\mathrm{E}_{1}$ & 400 & 403 & 395 \\
$+x, y(\mathrm{Mn})-x, y\left(\mathrm{O}_{3}, \mathrm{O}_{4}\right)$ & $\mathrm{E}_{2}$ & 225 & & \\
$z\left(\mathrm{O}_{2}, \mathrm{O}_{1}\right), x, y\left(\mathrm{O}_{4}\right)$ & $\mathrm{E}_{2}$ & 290 & 293 & 288 \\
$+x, y\left(\mathrm{O}_{1}, \mathrm{O}_{2}, \mathrm{O}_{4}, \mathrm{O}_{3}\right)-x, y(\mathrm{Mn})$ & $\mathrm{E}_{2}$ & 340 & 343 & \\
\hline \hline
\end{tabular}

later increase in lattice parameter $c$ is predominantly due to the weakened Jahn-Teller effect.

The elementary cell of $\mathrm{ErMnO}_{3}$ ferroelectric phase with P6 ${ }_{3} \mathrm{~cm}$ space group ( $a=6.117 \AA, c=11.456 \AA$ ) contains six formulas. According to the group-theoretical analysis, ${ }^{11}$ a total of $60 \Gamma$-point phonon modes $\left(10 \mathrm{~A}_{1}+5 \mathrm{~A}_{2}+10 \mathrm{~B}_{1}\right.$ $\left.+5 \mathrm{~B}_{2}+15 \mathrm{E}_{1}+15 \mathrm{E}_{2}\right)$ are predicted, in which there are 38 Raman-active modes $\left(9 \mathrm{~A}_{1}+14 \mathrm{E}_{1}+15 \mathrm{E}_{2}\right)$. Seven phonon modes are clearly observed in the ferroelectric phase at room temperature, as shown in Fig. 3. The highest intensity of $\mathrm{ErMnO}_{3}$ belongs to the $680 \mathrm{~cm}^{-1}\left(\mathrm{~A}_{1}\right)$ phonon mode corresponding to the apical oxygen $\left(\mathrm{O}_{1}, \mathrm{O}_{2}\right)$ stretching vibration along the $z$ axis around the $\mathrm{Mn}$ ions. In comparison with $\mathrm{ErMnO}_{3}$, the peaks of $\mathrm{ErFe}_{\mathrm{x}} \mathrm{Mn}_{1-\mathrm{x}} \mathrm{O}_{3}$ slightly shift to higher frequencies, while those of $\mathrm{ErCu}_{\mathrm{x}} \mathrm{Mn}_{1-\mathrm{x}} \mathrm{O}_{3}$ apparently shift to lower frequencies, which indicates the bond lengths of $\mathrm{ErMnO}_{3}$ shrink through $\mathrm{Fe}$ doping and extend through $\mathrm{Cu}$ doping. For example, frequency shifts in the $\mathrm{ErCu}_{\mathrm{x}} \mathrm{Mn}_{1-\mathrm{x}} \mathrm{O}_{3}$ system range from 2 to $5 \mathrm{~cm}^{-1}$ for the $680\left(A_{1}\right)$ and $290 \mathrm{~cm}^{-1}$ $\left(\mathrm{E}_{2}\right)$ phonon, as seen in Table $\mathrm{I}$. The peak intensities of the $638 \mathrm{~cm}^{-1}\left(\mathrm{E}_{1}\right)$ phonon for $\mathrm{ErFe}_{0.1} \mathrm{Mn}_{0.9} \mathrm{O}_{3}$ and the $395 \mathrm{~cm}^{-1}$ $\left(\mathrm{E}_{2}\right)$ phonon for $\mathrm{ErCu}_{0.1} \mathrm{Mn}_{0.9} \mathrm{O}_{3}$ become much larger than those of the undoped sample. The former phonon frequency, indicating the displacements of in-plane oxygen atoms $\left(\mathrm{O}_{3}\right.$, $\mathrm{O}_{4}$ ) in the $c$ plane, increases by $3 \mathrm{~cm}^{-1}$, whereas the latter phonon frequency, corresponding to the shifts of apical oxygen $\left(\mathrm{O}_{1}, \mathrm{O}_{2}\right)$ in the $c$ plane, decreases by $5 \mathrm{~cm}^{-1}$.

Figure 4 presents the field-cooled (FC) temperature dependence of the magnetic susceptibility $(\chi)$ of $\operatorname{ErMe}_{\mathrm{x}} \mathrm{Mn}_{1-\mathrm{x}} \mathrm{O}_{3}$

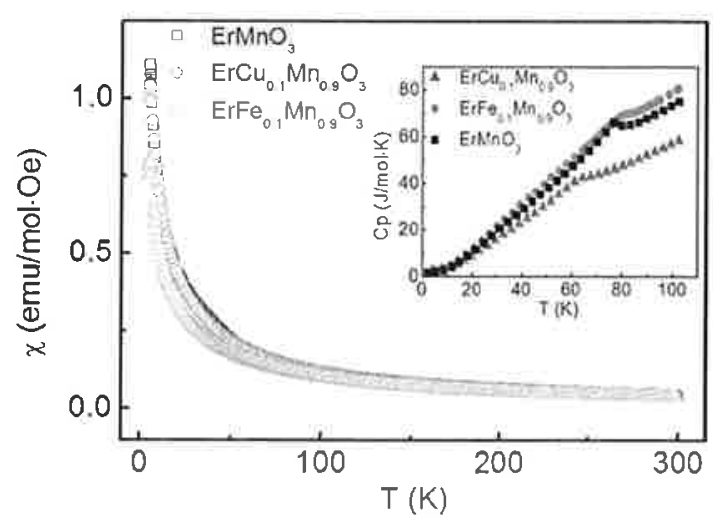

FIG. 4. (Color online) Temperature dependence of the Field-cooled magnetic susceptibility of $\mathrm{ErMe}_{\mathrm{x}} \mathrm{Mn}_{\mathrm{t}} \mathrm{O}_{3}(\mathrm{Me}=\mathrm{Cu}, \mathrm{Fe} ; \mathrm{x}=0,0.1)$ at $1000 \mathrm{Oe}$, and of the corresponding heat capacity (inset) measured without magnetic fields. 
$(x=0,0.1)$. The magnetic susceptibility of the samples exhibits paramagneticlike behavior with temperature. No clear magnetic transitions are observed over the whole temperature range. As the effective magnetic moment of $\mathrm{Er}^{3+}$ ions $\left(9.6 \mu_{\mathrm{B}}\right)$ is much larger than those of $\mathrm{Cu}^{2+}(1.7), \mathrm{Fe}^{3+}$ $\left(5.9 \mu_{\mathrm{B}}\right)$, and $\mathrm{Mn}^{3+}\left(4.9 \mu_{\mathrm{B}}\right)$ ions, the antiferromagnetic moments from transition metal ions are masked by the paramagnetic moment from the $\mathrm{Er}^{3+}$ ions. ${ }^{12}$ Moreover, the three $\chi$-T curves almost overlap, except for slight divergences at low temperature ( $\mathrm{T} \leq 50 \mathrm{~K}$ ), indicating weak improvement in the magnetization by transition-metal doping. However, the existence of magnetic transitions from the paramagnetic phase to the antiferromagnetic phase are verified by the characteristic $\lambda$-shape anomalies in the temperature dependence of the heat capacity, as shown in the inset of Fig. 4. $\mathrm{ErMnO}_{3}$ has an AFM transition at $77 \mathrm{~K}$. In contrast, the transition temperature is considerably reduced to $61 \mathrm{~K}$ for $\mathrm{ErCu}_{0.1} \mathrm{Mn}_{0.9} \mathrm{O}_{3}$ by $\mathrm{Cu}$ doping, while the transition temperature is enhanced to $79 \mathrm{~K}$ for $\mathrm{ErFe}_{0.1} \mathrm{Mn}_{0.9} \mathrm{O}_{3}$ by $\mathrm{Fe}$ doping. The variations of $T_{N}$ are consistent with the bond length evolutions suggested by Raman spectra.

In summary, the variations of lattice parameters of ErMe $_{x} \mathrm{Mn}_{1-\mathrm{x}} \mathrm{O}_{3}$ are ascribed to the combination of the JahnTeller effect and ionic sizes of the doping elements. Although only weak improvements in the magnetization are made by transition-metal doping, the Raman spectra indicates the bond lengths of $\mathrm{ErMnO}_{3}$ shrink through $\mathrm{Fe}$ doping and extend through $\mathrm{Cu}$ doping, which is in good agreement with the variations of $T_{N}$ in these two doping systems.

Authors X. L. Wang and Z. X. Cheng thank the Australian Research Council for support through Discovery Project Nos. DP0987190 and DP0558753.

'S. W. Cheong and M. Mostovoy, Nature Mater. 6, 13 (2007).

${ }^{2}$ R. Ramesh and N. A. Spaldin, Nature Mater. 6, 21 (2007).

${ }^{3}$ W. Prellier, M. P. Singh, and P. Murugavel, J. Phys.: Condens. Matter 17 R803 (2005).

${ }^{4}$ N. A. Spaldin, S. W. Cheong, and R. Ramesh, Phys. Today 63(10), 38 (2010).

5. Wang et al., Science 299, 1719 (2003).

${ }^{6}$ N. A. Spaldin and M. Fiebig, Science 309, 391 (2005)

${ }^{7}$ J. R. Sahu, A. Ghosh, A. Sundaresan, and C. N. R. Rao, Mater, Res. Bull. 44, 2123 (2009)

${ }^{8}$ Th. Lottermoser, M. Fiebig, D. Fröhlich, St. Leute, and K. Kohn, J. Magn Magn. Mater, 226-230, 1131 (2001)

${ }^{9}$ P. Liu, Z. X. Cheng, Y. Du, and X. L. Wang, J. Phys. D 43, 325002 (2010).

${ }^{10}$ M. C. Sekhar, S. Lee, G. Choi, C. Lee, and J. G. Park, Phys, Rev, B 72, $014402(2005)$

' D. L. Rousseau, R. P. Bauman, and S. P. S. Porto, J. Raman Spectrosc, 10, 253 (1981).

${ }^{12} \mathrm{~K}$. Yoshii and H, Abe, J. Solid State Chem. 165, 131 (2002). 